\title{
Protective Effect of bFGF on Bone Marrow Mesenchymal Stem Cell against Hydrogen Peroxide-Induced Apoptosis
}

\author{
Xiaoqing Gao¹, Guangqiang Hu ${ }^{1}$, Guangbi Fan'1, Zhiqiang Mei², Li Deng ${ }^{1}$, Jie Du1 ${ }^{*}$ \\ ${ }^{1}$ Department of Anatomy and Neurobiology, Sichuan Medical University, Luzhou, China \\ ${ }^{2}$ Preclinical Medicine Research Center, Sichuan Medical University, Luzhou, China \\ Email: *dujie75915@sohu.com
}

Received 27 January 2016; accepted 12 February 2016; published 18 February 2016

Copyright (C) 2016 by authors and OALib.

This work is licensed under the Creative Commons Attribution International License (CC BY).

http://creativecommons.org/licenses/by/4.0/

(c) (i) Open Access

\begin{abstract}
Bone marrow mesenchymal stem cells (BMSCs) transplantation has emerged as a promising treatment for various central nervous system diseases. However, oxidative stress results in poor survival of transplanted BMSCs in injury central nervous system (CNS). Basic fibroblast growth factor (bFGF) has been reported to have anti-apoptotic properties in serial of cells in oxidative stress. This study was designed to investigate protective effect and potential mechanisms of bFGF against hydrogen peroxide $\left(\mathrm{H}_{2} \mathrm{O}_{2}\right)$-induced apoptosis of BMSCs. BMSCs were pretreated with 20 $\mathrm{ng} / \mathrm{ml}$ of bFGF for 30 minutes, followed by exposure to $500 \mu \mathrm{M} \mathrm{H}_{2} \mathrm{O}_{2}$ and bFGF together for 1 hour. bFGF treatment significantly attenuated $\mathrm{H}_{2} \mathrm{O}_{2}$-induced cytotoxicity and apoptosis of BMSCs. Moreover, bFGF effectively decreased the levels of TNF- $\alpha$ and IL- 6 and increased expression ratio of Bcl-2/Bax in $\mathrm{H}_{2} \mathrm{O}_{2}$-induced BMSCs. The findings suggest that bFGF is likely to be an effectively protective agent against oxidative stress-induced apoptosis for BMSCs.
\end{abstract}

\section{Keywords}

Basic Fibroblast Growth Factor, Bone Marrow Mesenchymal Stem Cells, Hydrogen Peroxide, Oxidative Stress, Apoptosis, Mechanism

Subject Areas: Cell Biology

\section{Introduction}

Bone marrow mesenchymal stem cells (BSMCs) are multipotent adult stem cells in bone marrow that have the potential of stem cell differentiation and self-renewal. Studies have shown that BMSCs can differentiate into

*Corresponding author.

How to cite this paper: Gao, X.Q., Hu, G.Q., Fan, G.B., Mei, Z.Q., Deng, L. and Du, J. (2016) Protective Effect of bFGF on Bone Marrow Mesenchymal Stem Cell against Hydrogen Peroxide-Induced Apoptosis. Open Access Library Journal, 3: e2393. http://dx.doi.org/10.4236/oalib.1102393 
various cell types, including bone, cartilage, muscle, adipose, neural cells, and so forth in vitro under specific culture conditions [1]-[3]. Moreover, BMSCs possess many merits, such as easy acquisition in vitro, ability to express exogenous genes, minimal host immune rejection and capacity to produce growth factors and cytokines and engraft to the sites of injury [4]-[6], which make them be ideal choices for cell transplantation. Recent reports indicated that transplantated BMSCs provided a neuroprotection in degenerative disorders of the central nervous system (CNS). However, hostile microenvironments in injured CNS, such as oxidative stress, contribute to the pathological progression and have a negative impact on the survival of transplanted BMSCs [7]. Basic fibroblast growth factor (bFGF), a pleiotropic cytokine, can promote neural cell proliferate, survival [8] [9], and can induce BMSCs to differentiate into neuron-like cells and enhance the treatment effectiveness of BMSCs transplantation in CNS diseases [10] [11]. In addition, bFGF has properties of anti-oxidation and anti-apoptosis on serial of cells like neuron, photoreceptor cell and myocardial cell [12]-[14]. However, few studies have been conducted on bFGF protecting BMSCs from oxidative stress-induced apoptosis. This study was designed to investigate the protective effect and possible mechanisms of bFGF against hydrogen peroxide $\left(\mathrm{H}_{2} \mathrm{O}_{2}\right)$-induced apoptosis of BMSCs, which will contribute to furthering our understanding of the therapeutic effect of bFGFtreated BMSCs in transplantation strategies for CNS diseases, especially involved oxidative stress.

\section{Material and Methods}

\subsection{Reagents and Instruments}

Fetal bovine serum (FBS, Hyclone, USA); DMEM medium, 3-(4,5-Dimethylthiazol-2-yl)-2,5-diphenyltetrazolium bromide (MTT), 4',6-diamidino-2-phenyl-indole (DAPI) (Sigma, USA); Enzyme-linked immunosorbent assay (ELISA) Kit (Beijing Yonghui Biological Technology Co., Ltd., Beijing, China); The terminal deoxynucleotidyl transferase (TdT)-mediated dUTP-biotin nick end labeling (TUNEL) in situ cell death detection kit-POD (Roche Diagnostics Gmbh, Mannheim, Germany); Lactate dehydrogenase assay (LDH) Kit (Nanjing Jiancheng Bioengineering Institute, Nanjing, China); Olympus Fluorescence microscope (Japan); Microplate reader (BioTeK, ELX800, Vermont, American).

\subsection{MTT Assay}

BMSCs of C57BL/6 mouse were purchased from Cyagen Biosciences Inc, Guangzhou, China and maintained in DMEM medium containing 10\% FBS under $5 \% \mathrm{CO}_{2}$. To observe the effect of bFGF on proliferation of BMSCs, cells were plated in 96-well plates at a density of $5 \times 10^{3}$ cells/well in medium containing $20 \mathrm{ng} / \mathrm{ml} \mathrm{bFGF}$. The cells were continued for 48, 72 and 96 hours respectively. Moreover, to investigate the protective effect of bFGF against the cytotoxicity induced by $\mathrm{H}_{2} \mathrm{O}_{2}$, BMSCs were plated in 96-well plates at a density of $1 \times 10^{4}$ cells/well for 24 hours, then pretreated with $20 \mathrm{ng} / \mathrm{ml}$ bFGF for 30 minutes, followed by $500 \mu \mathrm{M} \mathrm{H}_{2} \mathrm{O}_{2}$ and bFGF together for 1 hour. Cell proliferation and viability were determined by MTT assay. Briefly, the cells were incubated with MTT reagent at a final concentration of $0.5 \mathrm{mg} / \mathrm{ml}$ at $37^{\circ} \mathrm{C}$ for 4 hours, and the absorbances were measured using a microplate reader at wavelength $490 \mathrm{~nm}$. BMSCs without any treatment were subjected to MTT assay served as control.

\subsection{LDH Release Assay}

The lactate dehydrogenase (LDH) is a useful biochemical marker of cell apoptosis or necrosis severity. Cell destruction induced by $\mathrm{H}_{2} \mathrm{O}_{2}$ was assessed by measuring the amounts of LDH released into the medium from injured BMSCs. Briefly, after BMSCs were pretreated with $20 \mathrm{ng} / \mathrm{ml}$ bFGF for 30 minutes, cells were explored to $500 \mu \mathrm{M} \mathrm{H}_{2} \mathrm{O}_{2}$ and bFGF together for 1 hour, and the supernatants were used for LDH activity analysis following the LDH assay Kit protocol. The absorbances of the samples were measured on the microplate reader at $450 \mathrm{~nm}$ wavelength.

\subsection{DAPI Staining and TUNEL Assay}

$\mathrm{H}_{2} \mathrm{O}_{2}$-induced apoptosis was detected by morphological observations done with DAPI staining and TUNEL assay. $\mathrm{H}_{2} \mathrm{O}_{2}$ and bFGF-treated BMSCs were fixed in $4 \%$ paraformaldehyde for 30 minutes. After permeabilising with $0.1 \%$ Triton X-100 for 10 minutes, the cells were dyed with DAPI staining Kit for 10 minutes, and then 
observed using a fluorescence microscope. TUNEL assay was performed with an situ cell death detection kit-POD according to the manufacturer's protocol. Briefly, endogenous peroxidase activity was quenched with $3 \%$ $\mathrm{H}_{2} \mathrm{O}_{2}$ for 10 minutes, followed by $0.1 \%$ Triton X-100 for 10 minutes to permeabilize cell membrane. The cells were incubated with TUNEL reagent for 60 minutes at $37^{\circ} \mathrm{C}$ in the dark, subsequently incubated with converter-POD for 30 minutes at $37^{\circ} \mathrm{C}$, and finally, samples were spotted with $\mathrm{DAB}$ and hematoxylin at the room temperature.

\subsection{ELISA Assays}

ELISA assays was used to detected pro-inflammatory cytokines, interleukin-6 (IL-6) and tumor necrosis factor- $\alpha$ (TNF- $\alpha$ ), apoptosis-related protein, Bax and Bcl-2. Briefly, after BMSCs were treated by $\mathrm{H}_{2} \mathrm{O}_{2}$ and bFGF, supernatants were collected for IL-6 and TNF- $\alpha$ analysis, and cells pellets were collected and repeated freezing and melting three times for Bax and Bcl-2 analysis. ELISA assays were performed following the manufacturer's protocol. The absorbances at $450 \mathrm{~nm}$ wavelength were determined using a microplate reader. According to the absorbances of the standard sample and the corresponding concentration value, a standard curve was drawn and the concentrations of IL-6, TNF- $\alpha$, Bax and Bcl-2 were calculated.

\subsection{Statistical Analysis}

The data were presented as mean $\pm \mathrm{SD}$. A statistical comparison was performed using one-way ANOVA. The data were from five independent experiments. $P$ value $<0.05$ was considered statistically significant.

\section{Results}

\section{1. bFGF Promoted Proliferation of BMSCs}

To determinate effect of bFGF on proliferation of BMSCs, cells were planted in medium with $20 \mathrm{ng} / \mathrm{ml} \mathrm{bFGF}$ for 48, 72 and 96 hours and were performed to MTT assay. The results showed that absorbances in the bFGF treated-BMSCs were significantly higher than those in the BMSCs after 48, 72 and 96 hours in culture $(P<$ 0.05), which suggested that bFGF promote BMSCs proliferation (Figure 1).

\section{2. bFGF Decreased $\mathrm{H}_{2} \mathrm{O}_{2}$-Induced Cytotoxicity}

To test the protective effect of bFGF on $\mathrm{H}_{2} \mathrm{O}_{2}$-induced cytotoxicity, the viability of BMSCs treated with $\mathrm{H}_{2} \mathrm{O}_{2}$ in the absence or presence of bFGF was assessed by MTT assay. As shown in Figure 2, MTT results showed the viability of both BMSCs and bFGF treated-BMSCs after treatment with $\mathrm{H}_{2} \mathrm{O}_{2}$ was significantly decreased compared to the BMSCs without any treatment $(P<0.05)$, however, when exposed to $\mathrm{H}_{2} \mathrm{O}_{2}$, the viability of bFGF treated-BMSCs was increased than that of BMSCs $(P<0.05)$, indicating bFGF suppressed the effect of $\mathrm{H}_{2} \mathrm{O}_{2}-$ induced cell death. Consistent with the results of MTT, the treatment of $\mathrm{H}_{2} \mathrm{O}_{2}$ significantly increased LDH

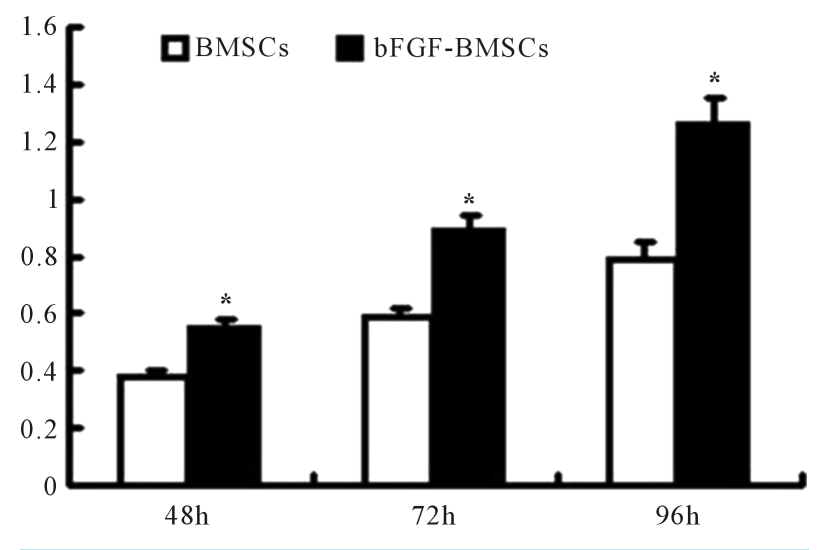

Figure 1. The promoting effect of bFGF on proliferation of BMSCs. Data were expressed as the mean $\pm \mathrm{SD}(\mathrm{n}=5) .{ }^{*} \mathrm{P}<$ 0.05 versus BMSCs. 
release in medium, but LDH release in bFGF treated-BMSCs was lower than that in BMSCs $(P<0.05)$, suggesting that bFGF decreased $\mathrm{H}_{2} \mathrm{O}_{2}$-induced cytotoxicity.

\section{3. bFGF Restrained $\mathrm{H}_{2} \mathrm{O}_{2}$-Induced Cell Apoptosis}

To determine whether bFGF inhibits apoptosis of BMSCs induced by $\mathrm{H}_{2} \mathrm{O}_{2}$, the apoptosis of BMSCs in either the presence or absence of bFGF was assessed by DAPI and TUNEL staining. DAPI staining showed that many apoptotic bodies or condensed nuclei were observed in BMSCs after exposure to $\mathrm{H}_{2} \mathrm{O}_{2}$, however, administration of bFGF brought obvious improvement compared to treatment with $\mathrm{H}_{2} \mathrm{O}_{2}$ alone (Figure 3). TUNEL staining was used to count the number of apoptotic cells induced by $\mathrm{H}_{2} \mathrm{O}_{2}$. The number of apoptotic cells in bFGF treated-BMSCs was lower than that in BMSCs following exposure to $\mathrm{H}_{2} \mathrm{O}_{2}(P<0.05$, Figure 3). The results suggested that bFGF decrease $\mathrm{H}_{2} \mathrm{O}_{2}$-induced cell apoptosis.

\section{4. bFGF Restrained Secretion of IL- 6 and TNF- $\alpha$ from BMSCs Induced by $\mathrm{H}_{2} \mathrm{O}_{2}$}

To investigate the potential mechanism by which bFGF inhibits $\mathrm{H}_{2} \mathrm{O}_{2}$-induced apoptosis in BMSCs, proinflammatory cytokines, IL-6 and TNF- $\alpha$, from BMSCs induced by $\mathrm{H}_{2} \mathrm{O}_{2}$ were determined. ELISA analysis revealed under $\mathrm{H}_{2} \mathrm{O}_{2}$-induced oxidative stress, BMSCs treated with bFGF had lower the expression of IL-6 and TNF- $\alpha$ than BMSCs $(P<0.05)$, indicating that treatment of bFGF significantly inhibited the $\mathrm{H}_{2} \mathrm{O}_{2}$-induced secretion of IL-6 and TNF- $\alpha$ from BMSCs, as shown in Table 1.
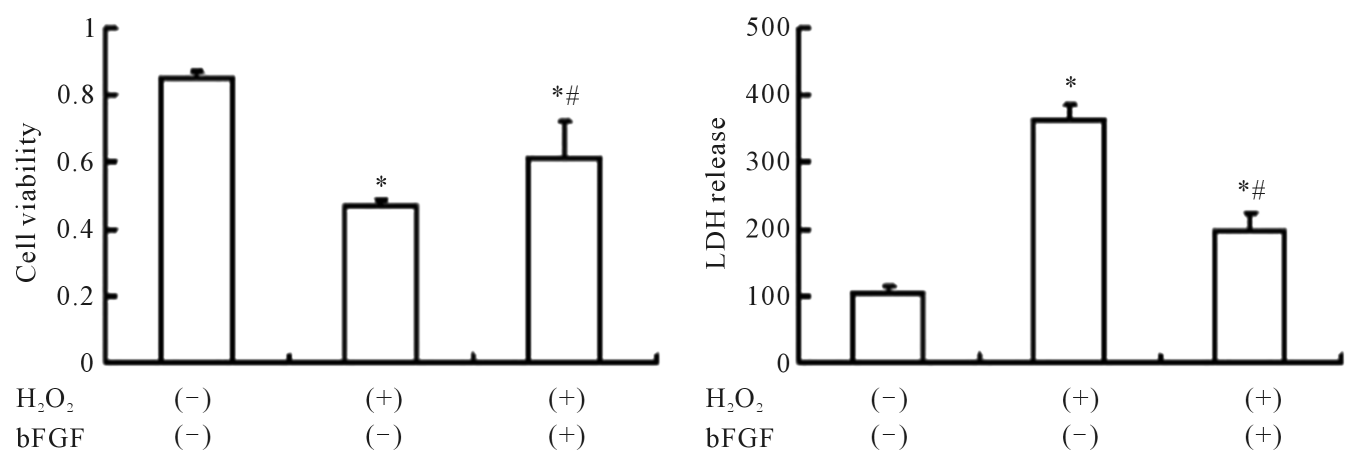

Figure 2. Promoting effect of bFGF on the viability and LDH release of BMSCs under $\mathrm{H}_{2} \mathrm{O}_{2}$-induced oxidative stress. Data were expressed as the mean $\pm \mathrm{SD}(\mathrm{n}=5) .{ }^{*} \mathrm{P}<0.05$ versus BMSCs without any treatment, ${ }^{\#} P<0.05$ versus BMSCs treated with $\mathrm{H}_{2} \mathrm{O}_{2}$ alone.

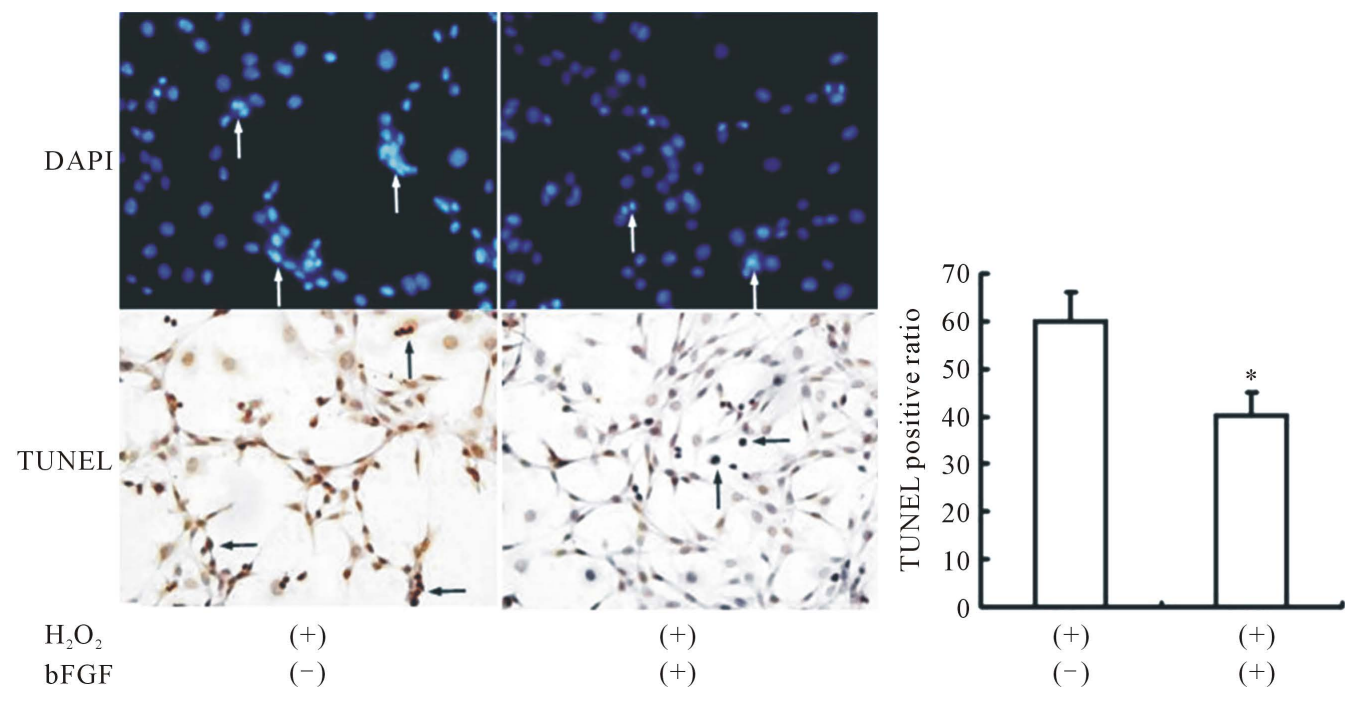

Figure 3. Inhibitory effect of bFGF on $\mathrm{H}_{2} \mathrm{O}_{2}$-induced apoptosis in BMSCs. Data were expressed as the mean $\pm \mathrm{SD}(\mathrm{n}=5) .{ }^{*} \mathrm{P}<0.05$ versus BMSCs treated with $\mathrm{H}_{2} \mathrm{O}_{2}$ alone. 
Table 1. Effect of bFGF on the expression of IL-6, TNF- $\alpha$ and Bcl-2/Bax ratio in BMSCs under oxidative stress (mean $\pm \mathrm{SD}, \mathrm{n}=5$ ).

\begin{tabular}{cccc}
\hline & IL-6 protein $(\mathrm{pg} / \mathrm{ml})$ & TNF- $\alpha$ protein $(\mathrm{pg} / \mathrm{ml})$ & Bcl-2/Bax ratio (\%) \\
\hline BMSCs & $68.11 \pm 6.63$ & $782.72 \pm 69.65$ & $7.18 \pm 1.44$ \\
bFGF treated-BMSCs & $40.96 \pm 6.62^{*}$ & $368.69 \pm 37.62^{*}$ & $17.95 \pm 3.28^{*}$ \\
\hline
\end{tabular}

${ }^{*} P<0.05$ versus BMSCs.

\section{5. bFGF Up-Regulated Bcl-2/Bax Ratio in BMSCs under Oxidative Stress}

To obtain the anti-apoptotic effect of bFGF, the expression of anti-apoptotic protein Bcl-2, and pro-apoptotic protein $\mathrm{Bax}$, were examined under $\mathrm{H}_{2} \mathrm{O}_{2}$-induced oxidative stress. The $\mathrm{Bcl}-2 / \mathrm{Bax}$ ratio has been believed to be more important than either promoter alone in deciding apoptosis [15]. So, we estimate Bcl-2/Bax ratio in cell pellets by ELISA analysis. The results showed under oxidative stress, the Bcl-2/Bax ratio in bFGF treatedBMSCs was higher than that in BMSCs $(P<0.05)$, suggesting that bFGF up-regulated Bcl-2/Bax ratio in BMSCs, as shown in Table 1.

\section{Discussion}

Accumulating evidence demonstrates that oxidative stress is associated tightly with neurodegeneration [16] and neuroinflammation [17]. BMSCs transplantation conduces to relief of functional deficits for CNS diseases, however, oxidative stress causes poor viability of transplanted cells, thus limiting BMSCs therapeutic exploitation [18]. Therefore, it is necessary to find ways to protect transplanted BMSCs from oxidative stress-induced apoptosis for the successful transplantation therapy.

As a mitotic growth factor, bFGF has been shown to have proliferative capacity on various cells, such as neural cells [19] [20], gastric epithelial cells [21] and embryonic germ cells [22]. Apart from the above cells, bFGF has also been reported to promote proliferation of BMSCs of dog and panda [23] [24]. In the present study, we showed bFGF promoted proliferation of BMSCs of mouse by MTT assay. Moreover, MTT and LDH analyses showed that viability of BMSCs was significantly decreased after exposure to $\mathrm{H}_{2} \mathrm{O}_{2}$ and bFGF significantly reversed this effect. These results suggest that bFGF protects BMSCs against oxidative stress, which are consistent with the previous reports [14] [25]. Besides, the results of TUNEL and DAPI staining showed that bFGF significantly decreased the apoptosis of BMSCs when exposed to $\mathrm{H}_{2} \mathrm{O}_{2}$. The results affirmed that death of BMSCs induced by $\mathrm{H}_{2} \mathrm{O}_{2}$ mainly results from apoptosis, and bFGF partly blocks this apoptosis. bFGF has been found to have powerful anti-apoptotic effects at various insults [12]-[14] [26]. However, the exact mechanisms need to explore.

TNF- $\alpha$ and IL-6, potent proinflammatory mediators, play a key role in initiating and sustaining the inflammatory response [27]. Meanwhile, TNF- $\alpha$ and IL-6 are also pro-apoptotic cytokines. For instance, they causes cell death via apoptosis through the activation of nuclear factor- $\mathrm{KB}(\mathrm{NF}-\mathrm{\kappa B})$ and transducer and activator of transcription 3 (STAT3) signaling pathways [28] [29]. bFGF possesses anti-inflammatory actions and cytoprotection effects. It involves Wnt signaling in neuronal and glial differentiation and exerts an anti-inflammatory activity to negatively control NF-кB pathway [30]. And it provides neuroprotection against neuronal death evoked by serum deprivation [31]. Moreover, adenovirus vector-heme oxygenase-1-transfected BMSCs were injected intramyocardially into rat hearts after myocardial infarction, the infarct size and cardiac performance were significantly improved, which was related with enhancement of bFGF and reduction of TNF- $\alpha$, IL- $1 \beta$ and IL-6 [32]. The present study showed that bFGF reduced the secretion of TNF- $\alpha$ and IL-6 induced by oxidative stress from BMSCs. Thus, our results indicated that bFGF protected BMSCs from oxidative stress-induced apoptosis by down-regulating the expression of TNF- $\alpha$ and IL-6 in BMSCs.

The Bcl-2 family proteins include both pro-apoptotic and anti-apoptotic members [33]. Bax, a pro-apoptotic member, increases reactive oxygen species generation and oxidative damage. Bcl-2, an anti-apoptotic member, produces a mild increase in cellular oxidative stress, resulting in increased anti-oxidant capacity and better ability to withstand additional oxidative stress [34]. bFGF has been found to have powerful anti-apoptotic effects. It protects glioblastoma cells through inducing the activation of STAT3 to increase the expression of pro-apoptotic genes and decrease the expression of anti-apoptotic genes [35]. And bFGF prevents ovarian granulosa apoptosis 
by involving the maintenance of normal levels of intracellular free calcium levels [26]. In addition, administration of bFGF prevented ischemia-induced myocardial cell death accompanied by the similar expression of Bax and greater expression of Bcl-2 [36]. In this study, we have provided the evidence that bFGF participates in modulating the balance of $\mathrm{Bcl}-2 / \mathrm{Bax}$ ratio under oxidative conditions. Therefore, we believed that bFGF restrainted apoptosis of BMSCs by modulating apoptosis-related protein.

\section{Conclusion}

In summary, we evaluated the effectiveness of bFGF for counteracting oxidative damage in cultured BMSCs. bFGF effectively prevents BMSCs from $\mathrm{H}_{2} \mathrm{O}_{2}$-induced cell apoptosis, reduces the levels of IL-6 and TNF- $\alpha$ and increases expression ratio of Bcl-2/Bax in BMSCs following treatment with $\mathrm{H}_{2} \mathrm{O}_{2}$. According to the current results, we suggest that bFGF has ability of anti-inflammatory actions and regulating apoptosis-related protein, and thus may be applied to promote BMSCs survival and therapeutic potential for the CNS diseases such as neurodegenerative diseases and brain injury which involve oxidative stress.

\section{References}

[1] Woodbury, D., Schwarz, E.J., Prockop, D.J. and Black, I.B. (2000) Adult Rat and Human Bone Marrow Stromal Cells Differentiate into Neurons. Journal of Neuroscience Research, 61, 364-370. http://dx.doi.org/10.1002/1097-4547(20000815)61:4<364::AID-JNR2>3.0.CO;2-C

[2] Scintu, F., Reali, C., Pillai, R., Badiali, M., Sanna, M.A., Argiolu, F., Ristaldi, M.S. and Sogos, V. (2006) Differentiation of Human Bone Marrow Stem Cells into Cells with a Neural Phenotype: Diverse Effects of Two Specific Treatments. BMC Neuroscience, 7, 14-25. http://dx.doi.org/10.1186/1471-2202-7-14

[3] Qian, D., Gong, J., He, Z., Hua, J., Lin, S., Xu, C., et al. (2015) Bone Marrow-Derived Mesenchymal Stem Cells Repair Necrotic Pancreatic Tissue and Promote Angiogenesis by Secreting Cellular Growth Factors Involved in the SDF1 $\alpha$ /CXCR4 Axis in Rats. Stem Cells International, 2015, Article ID: 306836. http://dx.doi.org/10.1155/2015/306836

[4] Deng, W., Han, Q., Liao, L., Li, C., Ge, W., Zhao, Z., You, S., Deng, H. and Zhao, R.C. (2004) Allogeneic Bone Marrow-Derived flk-1+Sca-1-Mesenchymal Stem Cells Leads to Stable Mixed Chimerism and Donor-Specific Tolerance. Experimental Hematology, 32, 861-867. http://dx.doi.org/10.1016/j.exphem.2004.06.009

[5] Kwon, D.S., Gao, X., Liu, Y.B., Dulchavsky, D.S., Danyluk, A.L., Bansal, M., et al. (2008) Treatment with Bone Marrow-Derived Stromal Cells Accelerates Wound Healing in Diabetic Rats. International Wound Journal, 5, 453463. http://dx.doi.org/10.1111/j.1742-481X.2007.00408.x

[6] Bergwerf, I., De Vocht, N., Tambuyzer, B., Verschueren, J., Reekmans, K., Daans, J., et al. (2009) Reporter GeneExpressing Bone Marrow-Derived Stromal Cells Are Immune-Tolerated Following Implantation in the Central Nervous System of Syngeneic Immunocompetent Mice. BMC Biotechnology, 9, 1-14. http://dx.doi.org/10.1186/1472-6750-9-1

[7] Schapira, A.H. and Jenner, P. (2011) Etiology and Pathogenesis of Parkinson's Disease. Movement Disorders, 26, 1049-1055. http://dx.doi.org/10.1002/mds.23732

[8] Namaka, M.P., Sawchuk, M., MacDonald, S.C., Jordan, L.M. and Hochman, S. (2001) Neurogenesis in Postnatal Mouse Dorsal Root Ganglia. Experimental Neurology, 172, 60-69. http://dx.doi.org/10.1006/exnr.2001.7761

[9] Zhang, H.Y., Zhang, X., Wang, Z.G., Shi, H.X., Wu, F.Z., Lin, B.B., et al. (2013) Exogenous Basic Fibroblast Growth Factor Inhibits ER Stress-Induced Apoptosis and Improves Recovery from Spinal Cord Injury. CNS Neuroscience \& Therapeutics, 19, 20-29. http://dx.doi.org/10.1111/cns.12013

[10] Xiong, N., Yang, H., Liu, L., Xiong, J., Zhang, Z., Zhang, X., et al. (2013) bFGF Promotes the Differentiation and Effectiveness of Human Bone Marrow Mesenchymal Stem Cells in a Rotenone Model for Parkinson's Disease. Environmental Toxicology and Pharmacology, 36, 411-422. http://dx.doi.org/10.1016/j.etap.2013.05.005

[11] Liu, Y., Yi, X.C., Guo, G., Long, Q.F., Wang, X.A., Zhong, J., Liu, W.P., et al. (2014) Basic Fibroblast Growth Factor Increases the Transplantation-Mediated Therapeutic Effect of Bone Mesenchymal Stem Cells Following Traumatic Brain Injury. Molecular Medicine Reports, 9, 333-339.

[12] Satoh, T., Enokido, Y., Kubo, T., Yamada, M. and Hatanaka, H. (1998) Oxygen Toxicity Induces Apoptosis in Neuronal Cells. Cellular and Molecular Neurobiology, 18, 649-666. http://dx.doi.org/10.1023/A:1020269802315

[13] O’Driscoll, C., Wallace, D. and Cotter, T.G. (2007) bFGF Promotes Photoreceptor Cell Survival in Vitro by PKAMediated Inactivation of Glycogen Synthase Kinase $3 \beta$ and CREB-Dependent Bcl-2 Up-Regulation. Journal of Neurochemistry, 103, 860-870. http://dx.doi.org/10.1111/j.1471-4159.2007.04827.x

[14] Wang, Z., Wang, Y., Ye, J., Lu, X., Cheng, Y., Xiang, L., et al. (2015) bFGF Attenuates Endoplasmic Reticulum 
Stress and Mitochondrial Injury on Myocardial Ischaemia/Reperfusion via Activation of PI3K/Akt/ERK1/2 Pathway. Journal of Cellular and Molecular Medicine, 19, 595-607. http://dx.doi.org/10.1111/jcmm.12346

[15] Del Poeta, G., Venditti, A., Del Principe, M.I., Maurillo, L., Buccisano, F., Tamburini, A., et al. (2003) Amount of Spontaneous Apoptosis Detected by Bax/Bcl-2 Ratio Predicts Outcome in Acute Myeloid Leukemia (AML). Blood, 101, 2125-2131. http://dx.doi.org/10.1182/blood-2002-06-1714

[16] Coombes, E., Jiang, J., Chu, X.P., Inoue, K., Seeds, J., Branigan, D., et al. (2011) Pathophysiologically Relevant Levels of Hydrogen Peroxide Induce Glutamate-Independent Neurodegeneration That Involves Activation of Transient Receptor Potential Melastatin 7 Channels. Antioxidants \& Redox Signaling, 14, 1815-1827. http://dx.doi.org/10.1089/ars.2010.3549

[17] Shen, J.N., Xu, L.X., Shan, L., Zhang, W.D., Li, H.L. and Wang, R. (2015) Neuroprotection of (+)-2-(1-Hydroxyl-4Oxocyclohexyl) Ethyl Caffeate against Hydrogen Peroxide and Lipopolysaccharide Induced Injury via Modulating Arachidonic Acid Network and p38-MAPK Signaling. Current Alzheimer Research, 12, 892-902. http://dx.doi.org/10.2174/156720501209151019111244

[18] Zeng, X., Yu, S.P., Taylor, T., Ogle, M. and Wei, L. (2012) Protective Effect of Apelin on Cultured Rat Bone Marrow Mesenchymal Stem Cells against Apoptosis. Stem Cell Research, 8, 357-367. http://dx.doi.org/10.1016/j.scr.2011.12.004

[19] Suzuki, Y., Yanagisawa, M., Yagi, H., Nakatani, Y. and Yu, R.K. (2010) Involvement of Beta1-Integrin Up-Regulation in Basic Fibroblast Growth Factor- and Epidermal Growth Factor-Induced Proliferation of Mouse Neuroepithelial Cells. Journal of Biological Chemistry, 285, 18443-18451. http://dx.doi.org/10.1074/jbc.M110.114645

[20] Ma, F., Xiao, Z., Chen, B., Hou, X., Han, J., Zhao, Y., et al. (2014) Accelerating Proliferation of Neural Stem/Progenitor Cells in Collagen Sponges Immobilized with Engineered Basic Fibroblast Growth Factor for Nervous System Tissue Engineering. Biomacromolecules, 15, 1062-1068. http://dx.doi.org/10.1021/bm500062n

[21] Luo, J.C., Lin, H.Y., Lu, C.L., Wang, L.Y., Chang, F.Y., Lin, H.C., et al. (2008) Dexamethasone Inhibits Basic Fibroblast Growth Factor-Stimulated Gastric Epithelial Cell Proliferation. Biochemical Pharmacology, 76, 841-849. http://dx.doi.org/10.1016/j.bcp.2008.07.010

[22] Park, T.S. and Han, J.Y. (2000) Derivation and Characterization of Pluripotent Embryonic Germ Cells in Chicken. Molecular Reproduction and Development, 56, 475-482. http://dx.doi.org/10.1002/1098-2795(200008)56:4<475::AID-MRD5>3.0.CO;2-M

[23] Colenci, R., da Silva Assunção, L.R., Mogami Bomfim, S.R., de Assis Golim, M., Deffune, E. and Penha Oliveira, S.H. (2014) Bone Marrow Mesenchymal Stem Cells Stimulated by bFGF Up-Regulated Protein Expression in Comparison with Periodontal Fibroblasts in Vitro. Archives of Oral Biology, 59, 268-276. http://dx.doi.org/10.1016/j.archoralbio.2013.11.017

[24] Wang, J.J., Liu, Y.L., Sun, Y.C., Ge, W., Wang, Y.Y., Dyce, P.W., et al. (2015) Basic Fibroblast Growth Factor Stimulates the Proliferation of Bone Marrow Mesenchymal Stem Cells in Giant Panda (Ailuropoda melanoleuca). PLoS ONE, 10, e0137712. http://dx.doi.org/10.1371/journal.pone.0137712

[25] Burdzińska, A., Bartoszuk-Bruzzone, U., Godlewski, M.M. and Orzechowski, A. (2006) Sodium Ascorbate and Basic Fibroblast Growth Factor Protect Muscle-Derived Cells from $\mathrm{H}_{2} \mathrm{O}_{2}$-Induced Oxidative Stress. Comparative Medicine, 56, 493-501.

[26] Peluso, J.J. (2003) Basic Fibroblast Growth Factor (bFGF) Regulation of the Plasma Membrane Calcium ATPase (PMCA) as Part of an Anti-Apoptotic Mechanism of Action. Biochemical Pharmacology, 66, 1363-1369. http://dx.doi.org/10.1016/S0006-2952(03)00486-6

[27] Debnath, T., Park, S.R., Kim, D.H., Jo, J.E. and Lim, B.O. (2013) Anti-Oxidant and Anti-Inflammatory Activities of Inonotus obliquus and Germinated Brown Rice Extracts. Molecules, 18, 9293-9304. http://dx.doi.org/10.3390/molecules18089293

[28] Park, J., Kang, W., Ryu, S.W., Kim, W.I., Chang, D.Y., Lee, D.H., et al. (2012) Hepatitis C Virus Infection Enhances TNF $\alpha$-Induced Cell Death via Suppression of NF- $\kappa$ B. Hepatology, 56, 831-840. http://dx.doi.org/10.1002/hep.25726

[29] Zhang, L., Tao, L., Shi, T., Zhang, F., Sheng, X., Cao, Y., et al. (2015) Paeonol Inhibits B16F10 Melanoma Metastasis in Vitro and in Vivo via Disrupting Proinflammatory Cytokines-Mediated NF- $\kappa$ B and STAT3 Pathways. IUBMB Life, 67, 778-788. http://dx.doi.org/10.1002/iub.1435

[30] Di Liddo, R., Bertalot, T., Schuster, A., Schrenk, S., Tasso, A., Zanusso, I., et al. (2015) Anti-Inflammatory Activity of Wnt Signaling in Enteric Nervous System: In Vitro Preliminary Evidences in Rat Primary Cultures. Journal of Neuroinflammation, 12, 23-41. http://dx.doi.org/10.1186/s12974-015-0248-1

[31] Hu, H.W., Li, X.K., Zheng, R.Y., Xiao, J., Zeng, J.Q. and Hou, S.T. (2009) bFGF Expression Mediated by a Hypoxia-Regulated Adenoviral Vector Protects PC12 Cell Death Induced by Serum Deprivation. Biochemical and Biophysical Research, 390, 115-120. http://dx.doi.org/10.1016/j.bbrc.2009.09.077 
[32] Zeng, B., Chen, H., Zhu, C., Ren, X., Lin, G. and Cao, F. (2008) Effects of Combined Mesenchymal Stem Cells and Heme Oxygenase-1 Therapy on Cardiac Performance. Europe Journal Cardiothoracic Surgery, 34, 850-856. http://dx.doi.org/10.1016/j.ejcts.2008.05.049

[33] Markou, T., Dowling, A.A., Kelly, T. and Lazou, A. (2009) Regulation of Bcl-2 Phosphorylation in Response to Oxidative Stress in Cardiac Myocytes. Free Radical Research, 43, 809-816. http://dx.doi.org/10.1080/10715760903071649

[34] Susnow, N., Zeng, L., Margineantu, D. and Hockenbery, D.M. (2009) Bcl-2 Family Proteins as Regulators of Oxidative Stress. Seminars in Cancer Biology, 19, 42-49. http://dx.doi.org/10.1016/j.semcancer.2008.12.002

[35] Wu, J., Feng, X., Zhang, B., Li, J., Xu, X., Liu, J., et al. (2014) Blocking the bFGF/STAT3 Interaction through Specific Signaling Pathways Induces Apoptosis in Glioblastoma Cells. Journal of Neuro-Oncology, 120, 33-41. http://dx.doi.org/10.1007/s11060-014-1529-8

[36] Nishida, S., Nagamine, H., Tanaka, Y. and Watanabe, G. (2003) Protective Effect of Basic Fibroblast Growth Factor against Myocyte Death and Arrhythmias in Acute Myocardial Infarction in Rats. Circulation Journal, 67, 334-339. http://dx.doi.org/10.1253/circj.67.334 